\title{
Entrepreneurial Stories, Narratives and Reading - Their Role in Building Entrepreneurial Being and Behaviour.
}

\section{Introduction}

The idea that the humanities can add to the understanding and practice of economic life has recently gained traction. Desai (2017), has mounted a convincing case that the humanities provide narratives that are a guide to good judgement, which he convincingly argues can't be reduced to formula. Desai's contention is that the humanities have the potential to ennoble finance: '...through stories that illuminate our lives and our work' (2017: xiii). Moreson and Schapiro (2017) argue that economists are too narrow in their: 'passion for mathematically based explanations', which means they struggle to account for at least three areas: 'culture, using narrative explanation, and addressing ethical issues that cannot be reduced to economic categories' (2017:xii). In response, they propose a dialogue of disciplines, with a greater emphasis on narratives in economics. Their view is that judgment cannot be formalized and that: 'Where human beings are concerned, stories are an indispensable way of knowing' (2017: 289). A common thread in this humanities focussed literature is that economics cannot be reduced to a set of universal laws (Bronk, 2009).

Shiller, an eminent economist has also written extensively on the importance of human psychology in economics (Akerlof and Shiller 2009; 2015) and for due weight to be given to 'social dynamics'(1984). He recently developed these insights by drawing attention to the importance of 'Narrative Economics', contending that the human brain is attuned towards narratives: in his analysis popular narratives are each specific to their time and have a distinct economic impact (2017). Schiller also discusses narrative psychology (Bruner 1986), and notes that research from a number of disciplines has confirmed that people invariably have little to say about their philosophy and objectives, but are far more willing to discuss personal stories that reveal much of their values (O’Connor, 2000).

In entrepreneurship there has been a coalescence around the importance of humanities and narrative based research . For example, according to Rao (1994) the ability to use stories is a requirement for becoming a successful entrepreneur. Further, Fled (2012) has written on the inspirational role of the stories of successful local entrepreneurs whose narratives detail how their start-ups achieved international success: these stories spur neophyte entrepreneurs to launch and persevere with their enterprises. Lounsbury and Glynn (2001) have also been noted that entrepreneurial stories confer legitimacy on new ventures and help create competitive advantage by two key forms: with firmspecific resource capital and industry-level institutional capital.

More recently, Markowska and Lopez-Vega have researched the importance of stories for developing regional identity, and they have been able to: ' ...identify entrepreneurial storying as a mechanism helping to facilitate the creation of conducive conditions for entrepreneurial action' (2018: 3). Further they argue that: 'Consequently, stories act as functional tools for individuals, particularly entrepreneurs' (2018: 6). Roundy and Bayer, also argue for stories in the construction of 'entrepreneurial ecosystems' (2018). In their view: 'Scholars are starting to examine a specific type of cultural resource, the shared narratives of EE participants (e.g., stories of recent entrepreneurship successes or from a region's entrepreneurial history), and to evaluate the importance of the values, goals, and beliefs narratives communicate' (2018:6). 
Building on this developing narrative and story-focussed literature, the purpose of this article is to explicate the novel concept of entrepreneurial reading as entrepreneurial learning - an autodidact behaviour used by entrepreneurs to create knowledge and resilience in response to the challenges, in organizational and entrepreneurial contexts. This research will therefore add to, and complement, the developing literature on entrepreneurial stories and narratives. The article also proposes an expanded perspective on entrepreneurship beyond its prevailing orthodox understanding, which is should be noted has been subject to sustained criticism (Rae, 2009). In contrast, the article constructs a conceptual framework that examines entrepreneurial reading in relation to contemporary developments in andragogy (i.e. adult-related learning).

Historically, the literature on entrepreneurial learning has been framed by a cognitivistinformed paradigm of individual learning, grounded in assumptions taken from experiential learning theory (ELT) (Kolb, 1984) Criticisms of this ELT perspective have noted its predilection on ordered, sequential and progressive representations of learning. By way of developing the literature and insights, this article proposes that entrepreneurial learning is conversely, a more complex process that is better understood from a span of theoretical perspectives (Anderson et al, 2012). Entrepreneurial learning is also an integrative (i.e. rather than singular or isolated) process that is prone to being fuzzy and idiomatic and likely to be conducted against a backdrop of chaos, crisis and complexity - all elements which are common to entrepreneurial activity rather than a stable, predictable environment. The research reviews an emerging entrepreneurial learning literature stream that recasts and recontextualises ELT. This literature stream expands the learning perspective beyond an over-reliance on sequential rational reflection with the incorporation of intermediate and more ad hoc temporal and contextual mechanisms, which translate experience and crises into learning and resilience. The review generates the following research question:

- How do entrepreneurs develop learning and resilience in response to crises through entrepreneurial reading?

The article proceeds by presenting an illustrative review of the conceptualization of adult learning theory in entrepreneurial learning literature, with reference to the dominant orthodoxies of ELT and transformative learning theory and the themes which inform them. The literature review makes a novel contribution in considering the underdeveloped domain of entrepreneurial learning literature and relates this to an entrepreneurial context more characterized by crises and a need for resilience than the oft-purported phased rationality. The article develops a research methodology connected with adult reading theory and semi-structured interviews with entrepreneurs on the materials they employ for their learning and produces a range of findings and subsequent discussion. The article then proceeds by discussing implications for future research and practice, before offering conclusions to expand the entrepreneurial learning perspective in relation to the complexities and felt-realities of entrepreneurial contexts.

\section{Literature Review: Entrepreneurial Learning}

Adult learning (i.e. andragogy) long-established orthodoxies were derived from the 
American liberal philosophy of pragmatism and enacted in the progressive movement in education (Wilson and Hayes, 2002). The founding text in this philosophy of education is Dewey's 'Experience and Education' (1934), and his theory which: '... defines learning as a continuous reorganization and reconstruction of experience that is embedded in social practice' (McHenry 2008:76). This legacy has endured. Kolb, for example, readily acknowledged Dewey's influence on the development of his 'experiential learning theory' (ELT) arguing that: 'Learning is the process whereby knowledge is created through the transformation of experience' (1984). Furthermore, leading educational scholars, including Knowles, notable for his andragogic assumptions (1975), and Mezirow, influential for his transformational learning theory (1975, 1978), have also acknowledged that their learning theories were developed within Dewey's pragmatist framework, with the core notion of reflecting on experience.

Kolb's ELT understands learning as a rational process, consisting of discrete and sequential stages of critical self-reflection, organizing learning into sub-components (reflective stages), and provides laws governing their interaction. Illustrative of this approach, are Honey and Mumford (2001) who developed a 'learning style' inventory, derived from Kolb's (1984) decomposition of knowledge, which classifies learners into four types: activist, theorist, pragmatist and reflector. Kolb has endured as the most influential theorist in entrepreneurial learning and his theory is derived from the principles of cognitivism, in which thinking is separated from thinking and action (Jones, et al, 2014:36). For example, Sullivan (2000) relies on Kolb's (1984) experiential theory of learning and critical incidents as emergent process to propose a highly sequential model of entrepreneurial learning. In a similar vein, Sullivan also refers to Churchill and Lewis' Small Firm Life Cycle Stage Theory (1983). Corbett further (1995) proposes a model based on the view that individuals from each of Kolb's learning styles will perform better during different stages of the entrepreneurial process. Moreover, Kolb's theoretical lens is also deployed by Politis (2005) who contends that much of the learning that takes place in an entrepreneurial context is, indeed, 'experiential in nature' - for example, in terms of the significance for learning of prior start-up experience, which provides tacit knowledge that enables entrepreneurs to recognize and exploit opportunities and respond to checks and crisis. Here, Politis argues in favour of grounding entrepreneurial experience into knowledge and clearly relates this to Kolb's ELT stages: concrete experience, reflective observation; abstract conceptualization; and active experimentation.

\section{Limitations of Experiential Learning Theory' (ELT)}

ELT influence has been all persuasive, however, gradually this orthodoxy has been questioned in andragogic literature. For example, Yorks and Kasl have criticized ELT:

\section{'...experience has been conceptualized as a resource that can be catalogued, objectified, and reflected on, instead of [viewing] experience as a verb or a felt encounter' (2002).}

It is also significant that ELT's core notion of rational reflection is contested, with its various interpretations being informed by four distinct intellectual traditions: ideological critique; psychologically inclined tradition; analytical philosophy and logic; and pragmatist constructivism (van Woerkham, 2010:341). The unifying thread in the various ELT interpretations is that they share: 
'... a common bias of instrumental rationality in the definition of critical reflection. All definitions implicitly characterize critical reflection as a systematic cognitive process that is targeted towards a specific ideal' (ibid) [Emphasis added].

And van Woerkham continues: 'All conceptualizations of critical reflection have a normative character, indicating 'good thinking' rather than describing observed ways of thinking' (ibid: 334). Thus, the pragmatist ideal of learning by experience, with its rationally structured reflective stages (Mezirow, 1978; Kolb, 1984) has been substantively challenged in adult learning theory. In response, Van Woerkham has developed an alternative learning perspective to reflect postmodernist interpretations that refute the Cartesian method of separating theory from practice - a characteristic of ELT (2010). She argues for the importance of concurrent and integrated learning processes, which can be implicit and therefore not available to critical reflection, as well as being driven by a broader understanding of rationality which includes subconscious and emotional imperatives (2010).

Resilience and Entrepreneurial Learning

ELT is therefore criticised for being unable to represent entrepreneurial learning and behavioural patterns; it is also taken as being increasingly remote from emergent workplace and organizational realities and lived experiences (Knights and Willmott, 1999). From this perspective, critical of ELT, there is a necessity to understand more deeply how entrepreneurs learn in the complex modern environments, and how this learning engenders characteristics such as resilience. Here, resilience can be understood as a characteristic or state of mind possessed by individuals in dealing with challenging circumstances (Fletcher and Sarkar, 2013; Pal, Torstensson, and Mattila, 2014; Masarik, 2015; Duchek, 2014; Bustinza et al. 2016). Resilience has tended to be discussed often in relation to major or macro-forms for example: political crises (for example Brexit in the United Kingdom), financial dilemmas (for instance - the 2008 capital market crisis); climate change and political events (Manyena, 2014; Walklate \& Mythen, 2014; Seligman, 2011; Cooke et al, 2016; King et al., 2016). However, the development of resilience is often played out at a more individual level in an everyday context and individual entrepreneurial learning and activity constitute a potent case in point. However, many organizational analyses do not tend to appreciate resilience beyond its affiliation with 'extreme' settings (Wang, Cooke \& Huang, 2014; Schultz \& van der Walt, 2015; Stokes et al, 2018). Thus, how entrepreneurs learn and develop resilience (Fletcher and Sarkar; 2013; Luthar et al, 2000:552) in response to daily life and crises is an important question (Bardoel, Pettit, De Cieri, \& McMillan, 2014; Wang, Cooke \& Huang, 2014) and entrepreneurial reading as entrepreneurial learning can play a significant role in developing understanding in this regard.

\section{Intuitive Learning}

The above developments in adult learning theories, and ELT in particular, have cast new light on the field of entrepreneurial learning and behaviour. Commonly, entrepreneurial decision-making techniques, are ascribed to ambiguous and intuitive forms of learning. For ELT orthodoxy, many entrepreneurial techniques would be regarded as irrational and hence less than optimum and consequently in need of corrective action. However, the challenges to the premise of ELT afford the opportunity to delve more deeply into the learning processes which inform entrepreneurial, 'acting on a hunch', reacting on 'gut instinct', 'sleeping on a problem', or how they arrive at a 
'spur of the moment decision based on intuition'. Further examples of the importance of experience for entrepreneurial learning include work on the role of mentors (Sullivan, 2000); algorithmic models for conceptualizing individual learning (Minniti and Bygrave, 2001); and discontinuous events in higher level learning (Cope 2003 and 2005). In consequence, Harrison and Leitch accurately reflected the research orthodoxy when they claimed that much of the literature had a propensity to underscore the importance of the role of experience and experiential learning for entrepreneurs (2008:3-23). Levesque et al, in concert with this, assert that at least in that regard there '... is a relatively large amount of literature on entrepreneurial literature and how entrepreneurs learn' (2009:549) (see also Harrison and Leitch, 2005, 2008; Rae 2007, 31; Schumpeter, 1934; Kirzner 1973; Minniti and Bygrave 2001; Gibb 2001, Cope 2005 and Politis 2005).

\section{Expanding the Entrepreneurial Learning Perspective}

However, while being generally framed by the linear and rationally-framed ELT orthodoxy, the entrepreneurial learning literature is also potentially infused by a range of wider and diverse interpretations, which offer interesting insights into how entrepreneurs engage crisis and develop resilience. For example, according to Leitch and Harrison, within the organizational and management literatures there is a growing interest in organizational learning and the closely related domain of knowledge management. Importantly, they indicate that relatively little of this research has been explored within the context or tradition of entrepreneurship (Leitch and Harrison, 2008: 3). Moreover, in a similar manner Easterby-Smith and Lyles (2003); Wang and Chugh, (2014) have all concluded that entrepreneurial literature lacks theoretical agreement and is at the nascent stage of development. By way of progression, whatever lacunae exist in relation to entrepreneurial learning, the present argument subscribes to Rae's view that entrepreneurial learning certainly needs to be approached more as a 'human process' (2000:145). This requires the breaking down of the false divide that exists between cognitivist methods of individual learning, (based on the assumptions of pragmatist rationality which frame ELT); and the interpretive model of learning (based on inductive inquiry) (Harrison and Leitch, 2005). Human processes embrace intermediate mechanisms that translate experience into learning through inter alia: underlying cognitive processes and deeply held beliefs (Kruger, 2007; Holcomb et al, 2009); the affective role of emotions on learning (Cope, 2005); entrepreneurial learning as a creative process involving peripheral vision (Chia, 2008); learning as an integrated and random process within experience, rather than as a sequential process of rationally reflecting on experience (Cunliffe and Easterby-Smith, 2004) and entrepreneurship as an art (Anderson and Jack's, 1999). Moreover, there is also scope to consider wider fields of research which may be relevant including, for example, Polanyi's theory of tacit knowledge (1958; 1966 grounded in learning literature (Nonaka and Takeuchi, $1995)$ and Rae's $(2000,2005)$ 'narrative interpretation' of human experience in the entrepreneurial learning context is also relevant whereby:

'...scholars suggest entrepreneurial practice is a narrative pursuit through which actors create their life stories' (Jones et al, 2014:17).

This article develops by analysing entrepreneurial reading habits that will generate a deeper understanding of how entrepreneurs select and use reading for learning and will also reveal knowledge in relation to, for example, the development of crisis coping mechanisms and resilience. The research also adds a new perspective to the: '...history 
of entrepreneurship [which] is replete with examples of illiterate and dyslexic entrepreneurs who have succeeded despite (or because of) this gift' (Smith, 2008: 292) and, significantly, also demonstrate that a significant group of entrepreneurs employ self-directed reading as a means of learning how to deal with the crises and challenges they have to confront.

\section{Entrepreneurial Learning and Critical Implications: Consideration of Five Prevalent Alternative Approaches and Themes to ELT}

A number of scholars have noted the centrality of learning for entrepreneurship (Minniti and Bygrave, 2001; Cope, 2005; Burt, 2005; Rae, 2007). It has also been argued that the learning perspective has revitalised entrepreneurial literature towards a practice perspective and away from the sterile search for entrepreneurial traits, which have been criticized for a lack of consistency and inability to link traits to performance (Rae, 2007:28; Jones et al, 2014:31). According to a recent literature review by Wang and Chugh (2014), and as indicated above, the two dominant theoretical perspectives in the entrepreneurial learning literature are the pragmatist inspired, practice-based experiential learning perspective; and an organizational learning theoretical perspective (2014:29). Their conclusion is that entrepreneurial learning: 'has become an important research area at the interface of entrepreneurship and organizational learning (ibid: 42). Given the limitations already outlined in relation to the ELT literature, there is thus particular interest in focusing on learning literature and its focus on the ego-centric level of the individual entrepreneur, rather than on the sociological level of the organizational perspective. This distinction is important in order to avoid the danger of ecology factors leading to inferences being drawn from an inappropriate level of analysis. Of course the different levels cannot be totally separated as there is always an inter-dependence of actions between micro (individual) and sociological/group (organizational) level outcomes as underlined by Popper's methodological individualism (1963), and conceptualized in sociology by Coleman in terms of 'Macro-to Micro and Micro-to Macro transitions' (1990:19-23). For entrepreneurial learning these theories are analogous with human capital theory (Becker, 1964) or as intellectual capital theory (Edvinsson and Malone 1997, and Nahapiet and Ghoshal 1998). However, the key point is that they are focused on how learning is accomplished at the level of the organization and therefore fall outside the scope of the present argument. The argument now elaborates five approaches and themes which develop alternatives to ELT: egocentric experiential learning; transformational learning; the sociology of interaction; schema theory; and mentoring.

First, for a focus at the ego-centric, that is at the individual entrepreneur, the most pervasive theme in extant ELT literature is based on various interpretations the intuitive notation of learning by experience. This is the original, and hence ancient understanding of learning processes:

'Tell me, and I will forget. Show me, and I may remember. Involve me, and I will understand' (Confucius approximately 450 BC).

Examples of this approach, include Minniti and Bygrave, who developed: 'A dynamic model of Entrepreneurial Learning', which argued for the importance of 'path dependency', with reference to Nelson and Winter's routines for problem solving (1982), and Williamson's transaction costs $(1975,1985)$. Their model posits that entrepreneurs learn from success and failure and consequently that 'history matters'. In 
their view entrepreneurial learning is generated by the reinforcement of the belief in certain actions due to their positive outcomes. They assert that this model replaces the perfectly rational agents of traditional economics with a model in which entrepreneurs learn from experience, while they process information and update their decisional algorithms.

The second theme in the entrepreneurial learning literature relates to transformational learning theory, which refers to learning that has a profound impact on the learner to be able to shift his or her world view (Meizrow, 1975, 1978, 1990 and 2000). Meizrow developed the concepts of 'meaning perspectives', comprising 'meaning schemes' which individuals acquire passively through experience and these operate as perceptual filters for understanding the meaning of experience. Importantly, for the present discussion, transformative learning occurs usually as an acute emotional response to a key event or crisis, for example, an entrepreneur whose business is going bankrupt would probably experience an unsettling paradigm shift in their thinking. However, Meizrow regarded critical reflection as being at the core of adult learning and therefore his theory follows the rational ELT sequence of critical reflection, reflective discourse and then action. By way of illustration, influenced by this theory, Cope argues that entrepreneurial learning is a continuous process, which has been theorized by a number of: ' ...dualistic conceptions of how people are supposed to learn', between lower and higher-level learning (2003: 432-435). Moreover, Cope references Meizrow (1990) to analyse these 'discontinuous events', arguing that his concept differs as the 'trigger event' does not necessarily have to be externally imposed (ibid, 441). Cope also acknowledges the significance of Meizrow's framework interpretation and the importance of critical reflection and the entrepreneur's emotional investment with their ventures - in other words, characteristics such as resilience involve an emotional dimension and are not a simple mechanistic dimension. In a later article, Cope develops his 'discontinuous events' concept with the notion of 'critical learning events' (2005:381-383), which he defined as dynamic phases that have the potential to create 'higher level learning outcomes'. Cope however, deviates from the rational ELT method in both of these articles by noting the importance of the emotional dimension in 'affective' entrepreneurial learning, with 'hard knocks' and the importance of: '...highly emotional relationship conflicts' in stimulating higher-level forms of entrepreneurial learning' (Ibid 389). Thus, Cope steps outside the entirely rational reflective model of ELT, which characterizes Meizrow's understanding of learning. This is perceptive insight, will be elaborated in the 'Findings and Discussion' section below.

The third theme in individual entrepreneurial learning draws its theoretical assumptions from the sociology of interaction, with reference to the social capital concept. The literatures on social capital and entrepreneurial learning are extensive and include, inter alia: Shaw and Conway, (2000, 367-383); Hoang and Antoncic, (2001); Jenssen and Greve, (2002: 254-267); Burt, (2002, 2005); Liao and Welsch, (2005:345-262); Carolis and Saparito, (2006:41-56); Anderson et al, (2007: 245-272); Casson and Della Guista, (2007:222-224). This work draws attention to the processes of how entrepreneurs accomplish situated learning through resources that inhere in their embedded egocentric networks. Thus, Burt has written extensively on entrepreneurship as a social capital learning process, in which brokerage in bridging networks provides a 'vision advantage' that facilitates different ways of seeing entrepreneurial opportunity (2002, 2005). Burt's different ways of seeing include the notion that tacit knowledge is hard 
to codify but essential for a business. Another example is from Carolis and Saparito who draw on social cognitive theory to argue that the impact of social capital on individual cognition is important in understanding entrepreneurial behaviour (2006:42). Their argument proposes that entrepreneurial behaviour can be explained as a nexus between internal (cognition) and external factors (social capital). Thus, there is interplay between the entrepreneur's embedded social capital networks, which shape their cognitive processes, and behaviour and this also points at social capital networks not only as a source of learning, but also as a resource to underpin and imbue resilience.

Schema theory represents the fourth theme. This theory gained prominence in reading research from the 1970s (McVee et al, 2005), though the schemata approach can be traced to the ancients in the writings of Plato (423-347 BC) and Aristotle (384-322 BC) , through to Kant (1724-1804) who understand schemas as organizing structures as follows:

'The schema of a concept... signifies a rule according to which my imagination can delineate the figure . . . (1781/1929, 182-183).

McVee's view is that schemata are a: ' ...lens that was both shaped and was shaped by experience' (Ibid, 2005:535). In reading theory, schemata provided a model for recognizing knowledge and organizing experience. Modern schemata theory is concerned with how the mind stores knowledge, and was pioneered by computer scientists, who conceptualized the mind as a machine (Minsk, 1975). Inspired by this research Anderson et al schemata have defined frames or scripts by asserting that they '... give generic characterizations of thing and events' (1978: 434). Ausbel's (1963 and 1968) research is also significant as he proposed that a reader's abstract cognitive structures provide the "ideational scaffolding" for the detailed information contained in text, in terms of 'scripts', which give generic characterizations of things and events. Thus interpretation is achieved in terms of a schema, which represents generic knowledge as they represents what the individual believes of true of a class of things, events, situations or people. It is through schemata that old knowledge influences new information. Thus, schematas, or frames (Minsky, 1975), are mental structures that incorporate general knowledge and impose generic characterizations.

The fifth theme is focussed on mentoring, essential to entrepreneurship (Sullivan 2000:168). Mentoring necessitates vertical power relations, comprising by definition unequal relationship: there is no point being mentored by an equal (horizontal tie): the idea is to tap into someone's greater experience, knowledge and resources. Moreover, this is also a dyadic process as:

'Mentoring involves principles from drawn from experiential and cyclical approaches to learning; the entrepreneur learns from experience but, with the mentor, learns, 'how to learn' from that experience' (Deakins and Whittam 2000, 126).

In consequence, the key components of a mentor-mentee relationship are conceptualized as being asymmetrical vertical power relationships, which facilitate dyadic (entrepreneurial) learning processes. 
To conclude, this review of entrepreneurial learning and andragogy, the discussion has identified five prevalent approaches and themes; experiential learning; transformational learning; the sociology of interaction; schema theory; and mentoring. There are commonalities between them, for instance a plausible case could be made for transformational learning being derived from the assumptions of experiential learning. Also common to these approaches is a focus on the human, the intuitive, the dynamic and changeable (unpredictable), that is to expand understanding beyond the ELT orthodoxy.

\section{Research Methods and Methodological Approach}

According to Wang and Chugh (2014:33) there is divide in the entrepreneurial learning literature between North American and European approaches. Harrison and Leitch have evaluated this divide as being between an American positivist deductive research method, and a European humanistic, interpretive inductive research (2005, 359-360). This research will be based in the European ontology on the subjectivity of knowledge with a qualitative methodology, contextualized in an interpretive paradigm. This design is consistent with the researchers' '...underlying ontological and epistemological assumptions (Leitch, Hill, and Harrison, 2010).

In consequence, a limitation is that the research findings cannot be generalized, '... as the meaning of experience is always contextually and temporally situated' (Cope, 2005:169). This research design, however, is able to offer insights and thick description (Geertz, 1973) of the reading processes of the entrepreneurs studied. Furthermore, qualitative techniques were considered most appropriate as the research aim is to increase understanding of the nature and role of reading processes; that is to search for a deep meaning behind the reading processes, and therefore adds to a developing qualitative literature stream into entrepreneurial learning including, for Anderson et al (2007) Cope (2003 and 2005), Cope and Watts (2003), and Rae (2000). The research will also address Wang and Chugh calls for further qualitative research into entrepreneurial reading (2014: 41).

The research was qualitative to investigate lived experience (Knights and Willmott, 1999) from the viewpoint of those being studied, with an emphasis on 'soft issues' to do with reading processes. Following Chell's recommendation the individuals were chosen: '. .. for analytical purposes to produce insight into the phenomena in question' $(2008,2012)$. This theoretical sampling was also purposeful in that it was based on the criteria that respondents would provide interesting examples of the phenomena being researched (Punch, 2005:187), and consequently provide the data for the analysis (Gartner and Birley 2002; Pratt 2009). This sample approach is based on giving knowledgeable individuals the opportunity to express their experiences in detail, in this instance on the importance of narratives and reading for entrepreneurship (Patton, 1990).

Data collection and analysis was achieved using an 'a priori' framework developed from the literature review. We employed a set of semi-structured interview questions to ensure that the critical research areas were addressed. The interviewers also encouraged respondents to include additional responses that they identified as important to their firms with reference to the research focus. This 'posteriori' approach informed the direction and length of the interviews, though all lasted at least one hour. 


\section{Sample Strategy and Descriptions}

The ten entrepreneurs, in the research sample were all selected within the parameters of the software/IT sectors, which are characterised by short life-cycles and continuous innovation that necessitates rapid learning processes (Sawyer and Gilsdorf, 2008:141167). In consequence, this sectoral focus was considered apt, as these entrepreneurs operate within intensely competitive markets, which requires continuous innovation for firms to survive and prosper.

The entrepreneurs in the sample were heterogeneous, which accords with previous research on the lack of consistency in the entrepreneurial personality (Chell, 2008: 210-243). One shared characteristic however, was that they were all industry veterans who had considerable IT work experience prior to them setting their own enterprises. A common view expressed was that it was difficult to see how you could set up a business without previous sectoral experience.

Table: Sample Research Population Details

\begin{tabular}{|c|c|c|c|}
\hline $\begin{array}{l}\text { Name: Nom de } \\
\text { guerre }\end{array}$ & Size & Sector & Self-description \\
\hline Bill & Micro & $\begin{array}{l}\text { IT/Consultancy } \\
\text { Education Services }\end{array}$ & $\begin{array}{l}\text { A fast-growing ITC service } \\
\text { sector firm. Bill had } \\
\text { considerable experience to } \\
\text { draw on from his time in } \\
\text { management consultancy in } \\
\text { blue-chip companies. }\end{array}$ \\
\hline Steve & Medium & $\begin{array}{l}\text { IT/Consultancy } \\
\text { Health Services }\end{array}$ & $\begin{array}{l}\text { At the time of the research } \\
\text { Steve was an investor-director } \\
\text { in five start-up companies. This } \\
\text { research focussed on Steve IT } \\
\text { firm, which provided services } \\
\text { to the NHS. }\end{array}$ \\
\hline Larry & Micro & $\begin{array}{l}\text { IT/Consultancy } \\
\text { Recruitment and } \\
\text { Management Consultancy }\end{array}$ & $\begin{array}{l}\text { To Larry being an IT } \\
\text { entrepreneur is about being } \\
\text { creative and structured. His } \\
\text { business approach is to, 'kill his } \\
\text { clients with kindness.' Larry } \\
\text { stressed that he was inspired to } \\
\text { start his own business after } \\
\text { reading Victor Kiam's 'Going } \\
\text { for it'. }\end{array}$ \\
\hline
\end{tabular}




\begin{tabular}{|c|c|c|c|}
\hline Paul & Micro & $\begin{array}{l}\text { IT/Consultancy Leisure } \\
\text { and Hospitality }\end{array}$ & $\begin{array}{l}\text { According to Paul the } \\
\text { owner/manager, this business is } \\
\text { concerned with 'skill led } \\
\text { delivery of end to end centre } \\
\text { solutions. }\end{array}$ \\
\hline Michael & Micro & $\begin{array}{l}\text { Religious/Social On-line } \\
\text { Services }\end{array}$ & $\begin{array}{l}\text { Michael was in his words, } \\
\text { 'obsessively interested' in the } \\
\text { virtual world for developing } \\
\text { business opportunities that } \\
\text { exploited his social } \\
\text { connections. }\end{array}$ \\
\hline Mark & Small & $\begin{array}{l}\text { International Recruitment } \\
\text { and Management } \\
\text { Consultancy Services }\end{array}$ & $\begin{array}{l}\text { Mark's firm aimed to develop } \\
\text { IT systems by building } \\
\text { Websites that both attract and } \\
\text { inform. }\end{array}$ \\
\hline Jack & Small & $\begin{array}{l}\text { IT/consultancy } \\
\text { B2B }\end{array}$ & $\begin{array}{l}\text { Jack's firm offers book- } \\
\text { keeping services for the self- } \\
\text { employed and operates in the } \\
\text { book publishing sector. }\end{array}$ \\
\hline Laurene & Medium & $\begin{array}{l}\text { IT/Consultancy } \\
\text { Education }\end{array}$ & $\begin{array}{l}\text { Laurene described herself as a } \\
\text { serial networker and sales- } \\
\text { woman in an educational IT } \\
\text { consultancy. }\end{array}$ \\
\hline William & Micro & $\begin{array}{l}\text { International } \\
\text { IT/Consultancy/recruitment }\end{array}$ & $\begin{array}{l}\text { William's firm is concerned } \\
\text { with, '...IT recruiting, in terms } \\
\text { of search, where we go and look } \\
\text { for candidates, and/or or } \\
\text { selection amongst existing } \\
\text { candidates, as well as } \\
\text { consultancy within the same } \\
\text { areas.' }\end{array}$ \\
\hline
\end{tabular}




\begin{tabular}{|l|l|l|l|}
\hline Allan & Micro & IT/Consultancy/Training & $\begin{array}{l}\text { Allan describes himself as } \\
\text { having a background in sales } \\
\text { and having a mission to bring } \\
\text { high quality ITC business } \\
\text { training to organisations. }\end{array}$ \\
\end{tabular}

Data Collection

All participants were interviewed on two occasions and the direction and length of the interviews was typically one hour but nevertheless were dependent on the emerging data. All interviews were recorded and subsequently transcribed.

The research dimensions were intended to give the investigation a flexible organization, to direct the research on where to look; that is to offer an initial focus for 'fixing attention upon one or a few attributes' (Stake, 2000:44). These themes and sensitizing dimensions were developed from the review of entrepreneurial learning literature as follows:

- Dynamic and Non-Linear Behaviour

- Reading and Transformative Events (higher and lower level learning)

- Reading and Social Interaction (sociocultural perspective)

The research was also consistently vigilant to identify and explore emergent themes, and in this sense was 'bottom up' and inductive (Cope, 2003). Further sources of data included reading the books referred to by the individual entrepreneurs, understanding their key themes and potential influence and observing the entrepreneurs at work. The research was conducted over six months and the findings were constantly compared and triangulated. Analysis was achieved by examining the data with reference to the sensitizing themes and dimensions using Silverman's constant comparison method (2005; 2015), and Glaser and Strauss's analytical induction (1967). This research understanding was also consistent with Silverman's criticisms on 'simplistic induction' (1997:1), as without these themes/dimensions to provide a theoretical focus: 'one would not recognise the field one was studying' (Silverman, 2005:78-80).

\section{Findings and Discussion: Reading and Entrepreneurial Learning}

\section{Dynamic and Non-Linear Behaviour}

The research findings confirmed a need to develop a reactive response to meeting challenges experienced at work. For example, one entrepreneur stated: 
'One thing I can understand from working out in the Middle East is relationships. At the same time I have had to read up and learn, well falconry, because some of the people that you deal with you have to have something in common with them that you can discuss'(Mark).

However, apart from being directed by experience to focus their reading on problem solving, the process of learning conceptualized in ELT did not accurately describe how the entrepreneurs understood or approached reading and learning. For example, reading was not linear or structured, but rather typically un-structured and hence not sequential, in the sense that the entrepreneurs would read chapters randomly, depending on what piqued their interest. The entrepreneurs were also unable to articulate how they reflected on their reading. In most of the entrepreneurs' responses, reflection was taken to mean thinking, which was understood as something vague and also self-evident. Thus, thinking and reflection were usually understood as a general construct; that is as a process that was not consciously willed, but occurred as a consequence of reading. The implication as that most reading inspired thinking/reflection took place at a subconscious level. Moreover, in the limited instances of the entrepreneurs consciously reflected, it occurred while they were applying their reading-based learning in practice. For illustration, one entrepreneur stated that he often asked himself: 'What would Victor Kiam do?' when he was confronted with a challenge at work. The ordered process of sequential stages described in the ELT was also entirely absent from his thought processes.

'One of the people who inspires me; I don't know if you remember him, is Victor Kiam, of Remington Steele. He loved it so much he bought the company! He has such passion and drive and determination. Whenever I first read his books, I thought my god this is amazing, and it gives you that desire and that passion. You have got to have a role model... I would have loved to have met him, because he has inspired me in so many ways.' [Larry]

In sum, the ordered, sequential process of learning conceptualized in ELT was not evident in the research data.

\section{Reading and Transformative Learning Events}

There was evidence that reading contributed to forms of both lower and higher learning. Lower level learning, which can be thought of as routines for problem solving (Nelson and Winter, 1982), was re-enforced by reading biographies and accounts of the entrepreneurial endeavours. Thus, the entrepreneurs would commonly read to reenforce routinized quotidian learning:

'There is a famous book called E-Myth by Michael Gerber... The myth is if you are very good at doing something then just by taking a risk with some money you will have a successful business...You have got to apply yourself as an entrepreneur to each area with equal importance. If you just focus on sales and marketing and get some fantastic leads coming through then you can't deliver' (Allan). 
Higher level learning as described by Cope (2003 and 2005) with reference to Meizrow's theories (1975, 1978, 1990 and 2000) was also highlighted in the research. For example, one entrepreneur talked at length how a previous venture had failed and he stated that reading Richard Branson's 'Screw it let's do it' (2007) had re-energized him to start again in business, but with a changed perspective to focus less on a worklife balance and more on financial success.

Another entrepreneur recounted how unethical business practices had led him to question the integrity of business in general. However, he recounted that he had reached a new perspective after reading Anita Roddick's, 'Business as Unusual: My Entrepreneurial Journey - Profits with Principles' (2005). The entrepreneur recounted that reading this book transformed his perspective, to see that business could be ethical and financially successful for entrepreneur, while serving wider society. Another entrepreneur stated that reading Ben and Jerry's, 'The Inside Scoop: How Two Real Guys Built a Business with a Social Conscience and a Sense of Humor' (Lager, 1994) had changed his perspective on the meaning of success for his business.

\section{Social Interaction and Reading}

There was no evidence that entrepreneurs were influenced in their choice of reading with reference to social networking or social capital. Thus, while one return of social capital is access difficult to to codify insider knowledge (Coleman, 1990), there was no evidence that entrepreneurs' choice of reading material was influenced by recommendations from ties in their social networks. The research confirmed that the entrepreneurs did not select their favoured reading material based on social network recommendation;. On the contrary, the selection of reading was directed by the idiosyncratic and entirely autodidactic choices of the individual entrepreneur.

\section{Emerging Theme One: Schemata as Informational Scaffolding for Reading}

The research generated two important emergent themes:

- Emerging Theme One: Schemata as Informational Scaffolding for Reading;

- Emerging Theme Two: Virtual Mentors-Research.

In this research it was evident that the entrepreneurs framed their reading within 4 schematas, as follows.

First, the 'poor boy' narrative, in which the belief was how a young man (and, apart from Anita Roddick, it was always a male), overcame a bad start in life or other barriers to emerge as a financially successful entrepreneur. These poor boy narratives did not necessarily refer to financial hardship; but also were concerned with overcoming other barriers to success that could include learning disabilities, for instance in Richard Branson's instance overcoming the challenges of dyslexia and a lack of academic success, after a highly expensive private education.

Second, the entrepreneur as hero narrative. In this schema it was taken that the individual had acted heroically to overcome various crises and daunting obstacles to achieve entrepreneurial success. The schema accords with the 'Great Man' view of history (Carr, 1984, 53-55), which is also analogous with the rebel or maverick as change agent, when an outstanding individual reshapes the world by dint of their will and energy. For example, the entrepreneurs exhibited a proclivity to read about 
successful individual entrepreneurs and their heroic quests for success including: Michael Gerber, Victor Kiam, Branson, Anita Roddick and Ricardo Semler. For example:

'In addition, I read every day... We don't have extensive network around our business, and large sales team. It is just my colleagues, and me and we need to make sure ourselves that we all deliver' (Bill).

'We need to make sure that we don't make the same mistakes that others have made before us! It is very interesting to read about other entrepreneurs that have succeeded before, and learn about what they did and did not do' (Jack).

The third schema was the perspective of entrepreneurs as storytellers, who entertain and inform through their telling of their entrepreneurial careers. In this schema the belief was that entrepreneurs were natural raconteurs and reading their accounts of business was a form of entertainment and reinforcement. Thus, one entrepreneur commented how he had recognized his own approach to management operations as reflecting Ricardo Semler's approach to building organizational culture, as described in, 'Maverick!: The Success Story Behind the World's Most Unusual Workplace' (1993).

The fourth schema identified very closely with autobiographical narratives. In this 'self as text' (Michelson 2012) the readers saw their life trajectories as reflecting the 'heroes' accounts described in biographies. In this schema the reading reinforced rather than challenged the ingrained values of the entrepreneurs. For example, an entrepreneur fixated on Victor Kiam commented that reading about his hero confirmed his view that individual initiative and tenacity could overcome apparently insurmountable obstacles. The research therefore supports the persistence of the trope of the entrepreneur as a hero, which is long-established (Warren, 2005).

\section{Emerging Theme Two: Virtual Mentors- Research}

The research respondents had not been experienced any mentoring relationships however, they did confirm that they would have appreciated advice from a successful and more established entrepreneur, especially in their first year of trading. To address this deficiency, these entrepreneurs sought to reflect and refine their entrepreneurial learning from reading books written by financially successful entrepreneurs. In their view this was a rational approach to learning, as who knew more about being an entrepreneur than a self-made business millionaire?

Thus, the research identified the role of virtual mentors in terms of literary mentors with the entrepreneurs reading style predicated on their assumption of asymmetrical power relations, which can be thought of as a virtual mentor-mentee relationship. For illustration, the authors selected were financially successful and self-confident, and the entrepreneurs were explicit in their aim of emulating this self-belief and financial success, by identifying any key lessons to be learnt to advance their own self-belief and financial returns. Thus, the entrepreneurs sought our virtual mentors who had achieved high self-worth and high status in terms of financial success.

\section{Conclusion and Implications}


This article was inspired by the recent literature on the interface of the humanities and the economy and has synthesized entrepreneurial learning literature, and reported on research, which confirmed that reading is an important resource for entrepreneurs. This research also challenges the assumptions of the dominant ELT learning paradigm in the existing entrepreneurial learning literature, as the reading in this investigation was intuitive and interactive, rather than sequential as suggested in the static and stage-based models of ELT. Knowledge seemed to be generated by entrepreneurs reading about how other entrepreneurs had encountered and overcome crises. These stories and narratives formed a resource that allowed the entrepreneurs to develop surrogate and latent forms of resilience in their own business activities. Furthermore, the research highlights the limits of ELT's foundations in rational critical reflection. Conversely, this research highlighted that the autodidactic character of the entrepreneurs reading. In this way their reading might be termed ad hoc or chaotic, reflecting the style of Montaigne, the early modern philosopher, who opined: 'I leaf, now through one book, now another, without order and without a plan, by disconnected fragments' (Bakewell, 2011:64-74).

The implications of this research are three-fold. First, there needs to be an acknowledgement that entrepreneurial, self-directed reading is important and worthy of further research. Second, entrepreneurial researchers need to take on board recent research from andragogy, which has expanded the adult learning perspective beyond the ELT to appreciate a more holistic understanding of learning processes. Entrepreneurs learn practical lessons on crises, as well as how to build resilience in relation to entrepreneurial reading. The third implication is to incorporate the reading material of entrepreneurs into an expanded pedagogical perspective on entrepreneurship, to include problem-based learning exercises and case studies based on popular best sellers, usually autobiographies and/or biographies. These popular autobiographies and biographies should be incorporated into entrepreneurship programmes, not because they add to learning about the entrepreneurial experience; but rather because they add to understanding of entrepreneurial learning processes as practised in the field.

\section{References}

Akerlof, G. A, and R. J. Shiller (2009) Animal Spirits: How Human Psychology

Drives the Economy and Why this Matters for Global Capitalism, Princeton:

Princeton University Press.

Akerlof, G. A, and R. J. Shiller (2015) Phishing for Phools: The Economics of

Manipulation and Deception. Princeton: Princeton University Press.

Anderson, A., D. Dodd, and S. Jack, (2012) Entrepreneurship as connecting: some implications for theorising and practice. Management Decision 50 (5): 958 - 971.

Anderson, A, Park J and Jack S (2007) Entrepreneurial Social Capital:

Conceptualizing Social Capital in New high-tech Firms. International Small Business Journal 25 (3): 245-272.

Anderson, R. C, Spiro R J and Anderson M C (1978) Schemata as Scaffolding for the Representation of Information in Connected Discourse. American Education Research Journal 15 (3): 433-440.

Ausubel, D. P. (1968/1978) Educational Psychology: A Cognitive View. New York and Toronto: Holt, Rinehart and Winston.

Bakewell, S. (2011) How to Live, A Life of Montaigne. London: Vantage. 
Bardoel, E. A., Pettit, T. M., De Cieri, H., \& McMillan, L. (2014). Employee resilience: an emerging challenge for HRM. Asia Pacific Journal of Human Resources, 52(3), 279-297.

Baron, R. A. and Markman, G.D. (2003) Beyond social capital: the role of entrepreneurs' social competence in their financial success. Journal of Business Venturing. Vol 18: 41-61.

Branson, R. (2007) Screw it, Let's do it. London: Virgin Books.

Bronk, R. (2009) The Romantic Economist: Imagination in Economics. Cambridge: Cambridge University Press.

Burt, R .S. (2005) Brokerage and Closure. Oxford: Oxford University Press. Bustinza, O. F., Vendrell-Herrero, F., Perez-Arostegui, M., \& Parry, G. (2016). Technological capabilities, resilience capabilities and organizational effectiveness. The International Journal of Human Resource Management, 1-23. Chell, E. (2008) The Entrepreneurial Personality, A Social Construction, (2nd Ed). East Sussex: Routledge.

Casson, M and Guista M D (2007) Entrepreneurship and Social Capital: Analysing the Impact of Social Networks on Entrepreneurial Activity from a Rational Action Perspective. International Small Business Journal 25 (3): 220-224.

Cooke, F.L., Cooper, B., Bartram, T., Wang, J. \& Mei, H. (2016), Mapping the relationships between high-performance work systems, employee resilience and engagement: a study of the banking industry in China. The International Journal of Human Resource Management, 1-22.

Cope, J. (2003) Entrepreneurial Learning and Critical Reflection: discontinuous events as triggers for 'higher-level' learning. Management Learning 34(4): 429- 450. Cope, J. and Watts, G. (2003) Learning by Doing-An exploration of Experience, Critical Incident and Reflection in Entrepreneurial Learning. International Journal of Entrepreneurial Behaviour and Research, 6, (3): 104-124.

Cope J. (2005) Toward a dynamic learning perspective of entrepreneurship. Entrepreneurship Theory and Practice, 29(4): 373-397.

Desai, M. (2017) The Wisdom of Finance: Discovering Humanity in the World of Risk and Return. Boston: Houghton Mifflin Harcourt.

Duchek, S. (2014) Growth in the Face of Crisis: The Role of Organizational Resilience Capabilities, Academy of Management Proceedings: 861-866. Easterby-Smith M and Lyles M (2003) The Blackwell Book of Organizational Learning and Knowledge Management. Oxford: Blackwell.

Edvinsson L and Malone M S (1997) Intellectual Capital: Realizing Your Company's True Value by Finding Its Hidden Brainpower. London: Harper Business. Feld, B. (2012) Startup communities: Building an entrepreneurial ecosystem in your city. John Wiley and Sons: Hoboken NJ.

Fletcher, D. and Sarkar, M. (2013). Psychological resilience: A review and critique of definitions, concepts, and theory. European Psychologist 18(1), 12-23.

Glaser, B. and Strauss A (1967) The Discovery of Grounded Theory. Chicago: Aldine. Gartner, W. B., Birley. S (2002). Introduction to the Special Issue on Qualitative Methods in Entrepreneurship Research. Journal of Business Venturing 17 (5): 387395.

Harrison, T. and Leitch, C. M. (2005) Entrepreneurial Learning: Researching the Interface Between Learning and the Entrepreneurial Context. Entrepreneurship Theory and Practice July: 351-371.

Holcomb, T. R, Ireland, R. D. Holmes, R. M .and Hitt, M. A. (2009) Architecture of Entrepreneurial Learning: Exploring the Link Among Heuristics, Knowledge and 
Action. International Journal of Entrepreneurial Behaviour and Research, Jan: 167192.

Jack, S. L. and Anderson, A. R. (1999) Entrepreneurship education within the enterprise culture: Producing reflective practitioners. International Journal of Entrepreneurial Behaviour and Research 5 (3): 110-125.

Jenssen, I. J, and Greve, A. (2002) Does the degree of redundancy in social networks influence the success of business start-ups? International Journal of Entrepreneurial Behaviour and Research 8 (5): 254-267.

Kant, I .(1781/1929) Critique of Pure Reason, New York: St Martin's Press. Knights, D. and Willmott, H. (1999) Management Lives, London, Sage Publications. Knowles, M. (1975) Self-directed Learning, Chicago: Associated Press, Follet.

King, D. D., Newman, A., \& Luthans, F. (2016). Not if, but when we need resilience in the workplace, Journal of Organizational Behavior, 37(5), 782-786.

Krueger, N. F. (2007) What Lies Beneath? The Experiential Essence of Entrepreneurial Thinking. International Journal of Entrepreneurial Behaviour and Research: Jan: 123-138.

Lager, F. C. (1994) Ben and Jerry's, The Inside Scoop: How Two Real Guys Built a Business with a Social Conscience and a Sense of Humor. New York: Crown Trade Publications.

Leitch, C. M., F. M. Hill, and R. Harrison. (2010). The Philosophy and Practice of Interpretivist Research in Entrepreneurship, Quality, Validity and Trust.

Organisational Research Methods 13 (1): 67-84.

Liao, J. and Welsch, H. (2005) Roles of Social Capital in Venture Creation: Key Dimensions and Research Implications. Journal of Small Business Management 43. (4): 345-362.

Lounsbury, M and Glynn M. A. (2001) Cultural Entrepreneurship: Stories, Legitimacy, and the Acquisition of Resources. Strategic Management Journal 22: 545-564.

Luthar, S. S., Cicchetti, D., \& Becker, B. (2000). The construct of resilience: A critical evaluation and guidelines for future work. Child Development, 71(3), 543. Manyena, S. B. (2014). Disaster resilience: A question of 'multiple faces' and 'multiple spaces'? International Journal of Disaster Risk Reduction, 8, 1-9.

Masarik, A. S., Martin, M. J., Ferrer, E., Lorenz, F. O., Conger, K. J., \& Conger, R. D. (2015). Couple resilience to economic pressure over time and across generations. Journal of Marriage and Family, in-press.

McHenry, J .(2008) The role and management of learning from experience in an entrepreneurial context. In: Harrison, R T and Leitch C M (Eds): Entrepreneurial Learning: Conceptual frameworks and applications. Oxon, pp 72-92.

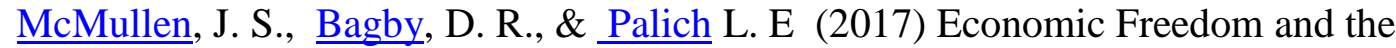
Motivation to Engage in Entrepreneurial Action. Entrepreneurial Theory and Practice, 32 (5): 875-895.

McVee, M. B., Dunsmore, K and Gavelek J. R. (2005) Schema Theory Revisited. Review of Educational Research 75 (4): 531-566.

Markowska, M, and H Lopez-Vega (2018) Entrepreneurial storying: Winepreneurs as crafters of regional identity stories. The International Journal of Entrepreneurship and Innovation 19 (4) : 282-297.

Mezirow, J. (1975) Education for perspective transformation: Women's re-entry programs into community colleges. New York: Centre for Adult Education. Teacher's College, Columbia University.

Mezirow, J. (1978) Perspective Transformation. Adult Education 28: 100-110. 
Mezirow, J. (2000) Learning to think like an adult: Core concepts of transformational theory. In: Mezirow J and Associates (Eds) Learning as transformation: Critical perspectives on theory in progress. San Francisco, Jossey-Bass, pp. 3-34.

Michelson, E. (2012) If the Self is a Text, What Genre is it? Structure and Ideology in Narratives of Adult Learning. Adult Educational Learning, 63 (3): 199-214.

Minsky, M. (1975) A Framework for Representing Knowledge. In: Winston P E (ed) The Pyschology of Computer Vision. New York: McGraw Hill, pp. 211-277. Morson, G. and M. Schapiro (2017) Cents and Sensibility: What Economics Can Learn from the Humanities. Princeton, Oxford: Princeton University Press Nonaka, I. and Takeuchi, H. (1977) The Knowledge Creating Company: How Japanese Companies Create the Dynamics of Innovation. New York: Wiley. Pal, R., Torstensson, H., \& Mattila, H. (2014). Antecedents of organizational resilience in economic crises - an empirical study of Swedish textile and clothing SMEs. International Journal of Production Economics, 147, 410-428.

Politis, D. (2005) The Process of Entrepreneurial Learning: A Conceptual Framework. Entrepreneurship Training and Practice. July, 399-424.

Pratt, M. G. (2009). For the Lack of a Boilerplate: Tips on Writing Up (and Reviewing) Qualitative Research. Academy of Management Journal 52 (5): 856-862. Punch, K. (2005) Introduction to Social Research: Quantitative and Qualitative Approaches, (2nd Ed) London: Sage.

Rae, D. (2000) Understanding entrepreneurial learning: a question of how? International Journal of Behaviour and Research 6 (3): 145-159

Rae, D. (2007) Entrepreneurship from opportunity to action. New York: Palgrave Macmillan.

Rae, D. (2009) Entrepreneurship: Too Risky to Let Loose in a Stormy Climate? The International. Journal of Entrepreneurship and Innovation, 10 (2) pp. 137-147.

Rao H. 1994. The social construction of reputation: certification contests, legitimation, and the survival of organizations in the American automobile industry, 1895-1912. Strategic Management Journal, Winter Special Issue 15: 29-44. Roddick A (2001) Take it personally: how to make conscious choices to change the world. London: Conari Press.

Roundy P T and M A Bayer, (2018) Entrepreneurial ecosystem narratives and the micro-foundations of regional entrepreneurship, The International Journal of Entrepreneurship and Innovation 25 (2): 232-248.

Sawyer, O.O and Gilsdorf J W (2008) An exploration of knowledge management processes in start-up firms in the high- technology sector. In: Harrison R T and Leitch C. M. (eds) Entrepreneurial Learning, Conceptual frameworks and applications. Oxon: Routledge, pp.141-167.

Seligman, M. (2011) Building Resilience. Harvard Business Review. April 100-109. Semler, R. (1993) 'Maverick!: The Success Story Behind the World's Most Unusual Workplace'. New York: Warner Books.

Schultz, C., \& van der Walt, H. (2015). Reinventing HR: Strategic and Organisational Relevance of the Human Resources Function. Knowres Publishing. Shaw, E, and Conway, S (2000) Networking and the small firm. In: Carter, S. and Jones- Evans, D. (eds) Enterprise and Small Business: Principles, Practice and Policy. Harrow: Financial Times. Prentice Hall, pp. 367-383.

Shiller, R. J. (1984), Stock Prices and Social Dynamics, No 719R, Cowles Foundation Discussion Papers, Cowles Foundation for Research in Economics, Yale University, https://EconPapers.repec.org/RePEc:cwl:cwldpp:719r. 
Shiller, R. J (2017) Narrative Economics. American Economic Review, 107(4): 9671004.

Silverman, D. (1985) Qualitative methodology and sociology: describing the social world. Aldershot: Ashgate Publishing.

Silverman, D. (2000) Doing Qualitative Research: A Practical Handbook. London:

Sage.

Silverman, D. (2017) Interpreting Qualitative Data. London, Sage.

Smith R (2008) Being differently abled: learning lessons from dyslexic entrepreneurs. In: Harrison T and Leitch C M (eds) Entrepreneurial Learning: Conceptual frameworks and applications. New York: Routledge.

Stokes, P., Smith, S., Wall, T., Moore, N., Rowland, C., Ward, T., \& Cronshaw, S. (2018). Resilience and the (micro-) dynamics of organizational ambidexterity: implications for strategic HRM. The International Journal of Human Resource Management, 1-36.

Walklate, S., \& Mythen, G. (2014). Contradictions of Terrorism: Security, Risk and Resilience. Routledge.

Wang, J., Cooke, F. L., \& Huang, W. (2014). How resilient is the (future) workforce in China? A study of the banking sector and implications for human resource development. Asia Pacific Journal of Human Resources, 52(2), 132-154.

Wang, C. L. and Chugh, H. (2014) Entrepreneurial Learning: Past Research and Future Challenges. International Journal of Management Reviews, (16), 24-61. Warren, L. (2005) Images of Entrepreneurship: Still Searching for the Hero? The International Journal of Entrepreneurship and Innovation, (6, 4), 221-229. 